\title{
The influence of Image and Service Value on Mobile Banking Loyalty
}

\author{
A. Fragata \\ Viseu Polytechnic Institute, \\ CI\&DEI- Centro de Estudos em Educação e Inovação \\ H. Teixeira \\ Viseu Polytechnic Institute, \\ CI\&DEI- Centro de Estudos em Educação e Inovação \\ L. Cruz-Lopes \\ Viseu Polytechnic Institute, \\ CERNAS- Center for Studies in Natural Resources Environment and Society
}

\begin{abstract}
This paper intends to empirically examine the impact of Image and Service Value on Mobile Banking Services Loyalty. The data was analysed by employing exploratory as well as confirmatory analysis and a Structural Equation Model was extracted from 120 Portuguese respondents. The results suggest that Image and Service Value are positively related with Mobile Banking Loyalty. We also found a strong impact of Image on the Perceived Service Value.
\end{abstract}

Keywords: Mobile Banking, Loyalty, Image, Service Value.

\section{INTRODUCTION}

Mobile banking is defined as a product or service offered by a bank for conducting financial and non-financial transactions, using a mobile device, namely mobile phone, smartphone or tablet [1]. Mobile banking is among the latest in a series of recent mobile technological wonders. Although automated teller machine (ATM) and Internet banking offer effective delivery channels for traditional banking products, but as the modern delivery channel established by retail and banks in many developed and developing countries, mobile banking is likely to have significant effects on the market. In particular, the expanded uses of smartphones has increased demand for mobile banking services, prompting many more banks, software houses and service providers to offer this innovative service. It comes with new sets of products and applications designed to extend their client reach (including to unbanked populations), improve customer retention, enhance operational efficiency, increase market share, and provide new employment opportunities [2]. Mobile banking is already a pervasive trend; according to Business Insider Intelligence's Mobile Banking Competitive Edge Study in [3], 89\% of survey respondents said they use mobile banking, but according to [4] in a study conducted in Portugal, only 53,5 \% of the respondents used the services of Mobile Banking. [5] addresses the area of customer loyalty among mobile banking customers in India, which limits the generalizability because of cultural and societal differences. Although, the findings by [5] imply that the most important variable affecting loyalty is customer satisfaction, while usability has an indirect effect on loyalty through satisfaction as a mediator. In a study conducted by [6] that service quality as a whole, is a strong antecedent of customer satisfaction, but only three dimensions have a positive influence on satisfaction (reliability and responsiveness, efficiency and convenience) and two of them on customer retention (reliability and efficiency). In [7] it is confirmed that trust significantly and positively impacts 
commitment/satisfaction. Mobile banking service quality dimensions also influence trust and commitment/satisfaction. Trust is associated with security/privacy and practicity (regarded as utilitarian factors), while commitment/satisfaction is driven by enjoyment and sociality (dimensions more hedonic by nature). Research about customer loyalty in mobile banking is still in its infancy and further research is needed to better understand which factors affect loyalty within mobile banking.

\section{LITERATURE REVIEW}

According to [8] on the last decade's bankers have experimented with a multitude of programs and tactics to strengthen customers' bonds of loyalty to their institutions. In the process, these banks are confronted with the following problems (i) banks continue to struggle with loyalty programs: how to create them, how to measure loyalty, what rewards are appropriate, (ii) measuring customer loyalty means quantifying customer attitudes and behaviours accurately, which can be difficult (iii) retail banks rarely have the competency and capability to accurately measure the profitability of their customers and (iv) a sophisticated loyalty program should be based on the concept of a fair value exchange between or among partners and (iv) retail banks need to move away from product-centric loyalty programs toward those that reward an entire relationship.

The definition of perceived value in [9] is "the overall assessment on the product (or service) utility determines by customer's perceptions of what is received and what is given". In services, it involves the comparison of what one is getting (i.e., benefits) and what he has to give up (i.e., sacrifices) in order to receive the service [10]. Therefore, perceived value of mobile banking service in this study mean the customers' overall perception of it benefits and sacrifices needed to use it. Customers are highly interested in the benefits that a service would offer them once it is used. In essence, the customer seeks to establish the value that the service will add in his or her life before making the decision to adopt. Accordingly, the service must be able to satisfy the needs of the customer and provide benefits that make the service worth to adopt. This study addresses the benefit factors that mobile banking customers look out for performance expected and level of effort required. The costs of the service are considered as one of the most imperative factors in the decision making process. This is because it determines the customer's ability to use the service depending on availability of the specified amount and their set budget. Perceived cost is the perceived quantifiable costs of acquisition and use of technology. Perceived financial cost is defined as "the extent to which a person believes that using mobile banking will cost money" [11].

According to [12] the corporate Image is the perception of an organization held in consumer's memory, who works as a type of filter influencing the perception of how the company operate. The consumers' willingness to continue a contractual relationship with a mobile services' company is strongly influenced by the extent to which they have a positive image. Additionally, consumers' perceptions of the mobile services company, such as integrity, reliability or experience are crucial, since customers evaluate corporate attributes before they sub- scribe. More specifically, when customers perceive that a mobile services company is reliable, trustworthy and with wide experience, they will be more satisfied [13]. In [14] is also analyzed by the results that service quality and customer satisfaction have high impact on the customer perceived value where corporate image also effected the customer perceived value. In a study conducted by [15] the authors found that service quality directly influences both perceived value and image perceptions, that value and image influence satisfaction, that corporate image influences value, and that both customer satisfaction and value are significant determinants of loyalty. Thus, value has both a direct and indirect (through satisfaction) impact on customer 
loyalty. Other variables mediate the impact of both service quality and corporate image on customer loyalty.We then propose the following Hypothesis:

H1: The Service Value is positively related with Mobile Banking Loyalty

H2: The Image is positively related with Mobile Banking Loyalty

H2: The Image is positively related with Service Value

\section{METHODOLOGY}

This study is based on both primary and secondary data sources. Primary data was collected through interviews with Mobile Banking users as well as non-users. We collected data in November 2019 and 120 valid responses were obtained. We then used SPSS 26 for exploratory and confirmatory analysis and AMOS 26 for Structural Equation Modelling.

\section{FINDINGS}

In Table I we present the demographic characteristics of the sample and Figure I outlines the most used Portuguese banks for the respondents in our sample.

Table I Demographic characteristics of the sample

\begin{tabular}{|c|c|c|}
\hline \multicolumn{2}{|c|}{ Demographic variable } & Percent \\
\hline \multirow{5}{*}{ Age } & $<18$ & 0 \\
\hline & $19-30$ & 20 \\
\hline & $31-40$ & 32,5 \\
\hline & $41-65$ & 46,7 \\
\hline & $>65$ & 0,8 \\
\hline \multirow{5}{*}{ Education } & $\mathrm{PhD}$ & 10,8 \\
\hline & Master & 15,8 \\
\hline & Degree & 48,3 \\
\hline & Secondary school & 22,5 \\
\hline & Another & 2,6 \\
\hline \multirow{5}{*}{$\begin{array}{l}\text { Month } \\
\text { Income } \\
€\end{array}$} & $<500$ & 13,3 \\
\hline & $501-1000$ & 24,2 \\
\hline & $1001-1500$ & 29,2 \\
\hline & $1501-2000$ & 15 \\
\hline & $>2000$ & 18,3 \\
\hline
\end{tabular}

In our sample 78,3\% are using the App of their main bank, so our findings indicate a high penetration in the target market and therefore, the potential of this market should not be underestimated. In Figure I we present the percentage of the main bank App used by the respondents and in Figure II, we present the frequency in using the mobile services of the main bank. In Figure III, we present a graph with results about the affirmation if they consider themselves loyal to their main bank App for mobile banking services.

In figure IV we present the proposed structural equation model and in Table II we present the results of the exploratory and confirmatory analysis. Model fit criteria suggested by [16] were used for both the measurement and the structural model: X2/df, goodness of fit (GFI), adjusted goodness of fit (AGFI), comparative fit index (CFI), root mean square residual (RMR) and root mean square error of approximation (RMSEA). Acceptable models should have X2/df $<=3$, 
AGFI $>=0.80$, RMR $<=0.1$, RMSEA $<=1.0$ and GFI and CFI higher than 0.90. The global fit for the present structural equation model was acceptable: $X^{2}=29,9, d f=18$; GFI $=0,937$; RMSEA $=0,075, \mathrm{AGFI}=0,874$ and $\mathrm{CFI}=0,818$ and $\mathrm{RMR}=0,044$. Our results indicate that we can accept the proposed Hypothesis 1 that Service Value is positively related with Mobile Banking Loyalty with a direct effect of 0,52 and also that we can accept the proposed Hypothesis 2 that the Image is positively related with Mobile Banking Loyalty with a direct effect of 0,48. For Hypothesis 3 we found an important impact of Image on Service Value, accepting also the proposed Hypothesis 3.

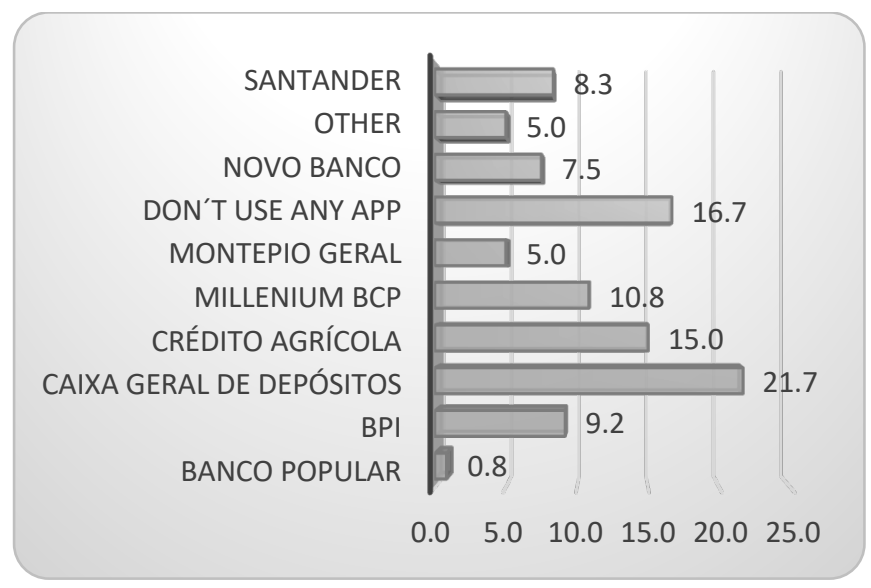

Figure I- Main bank App used

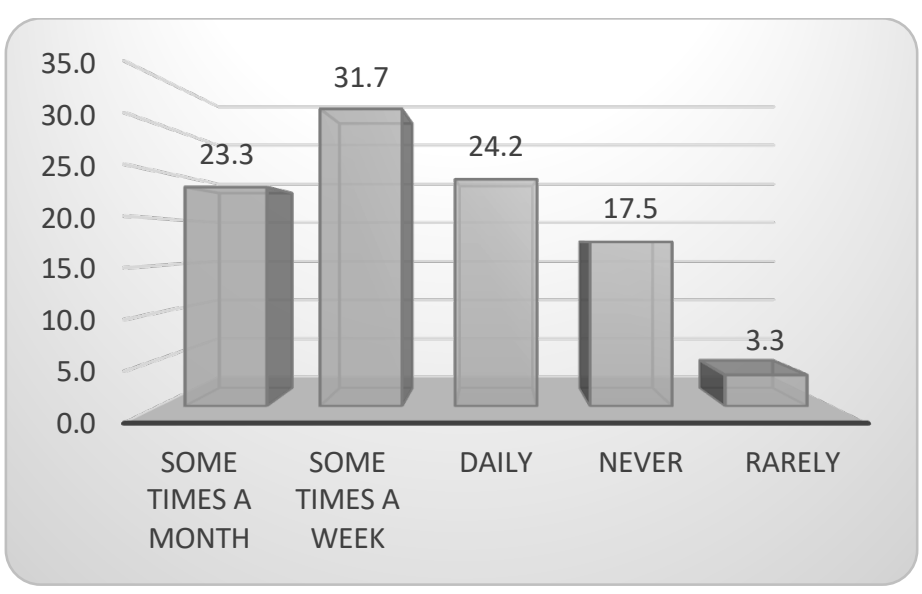

Figure II - Frequency in using the main bank App

Figure III- Loyalty to the main bank App

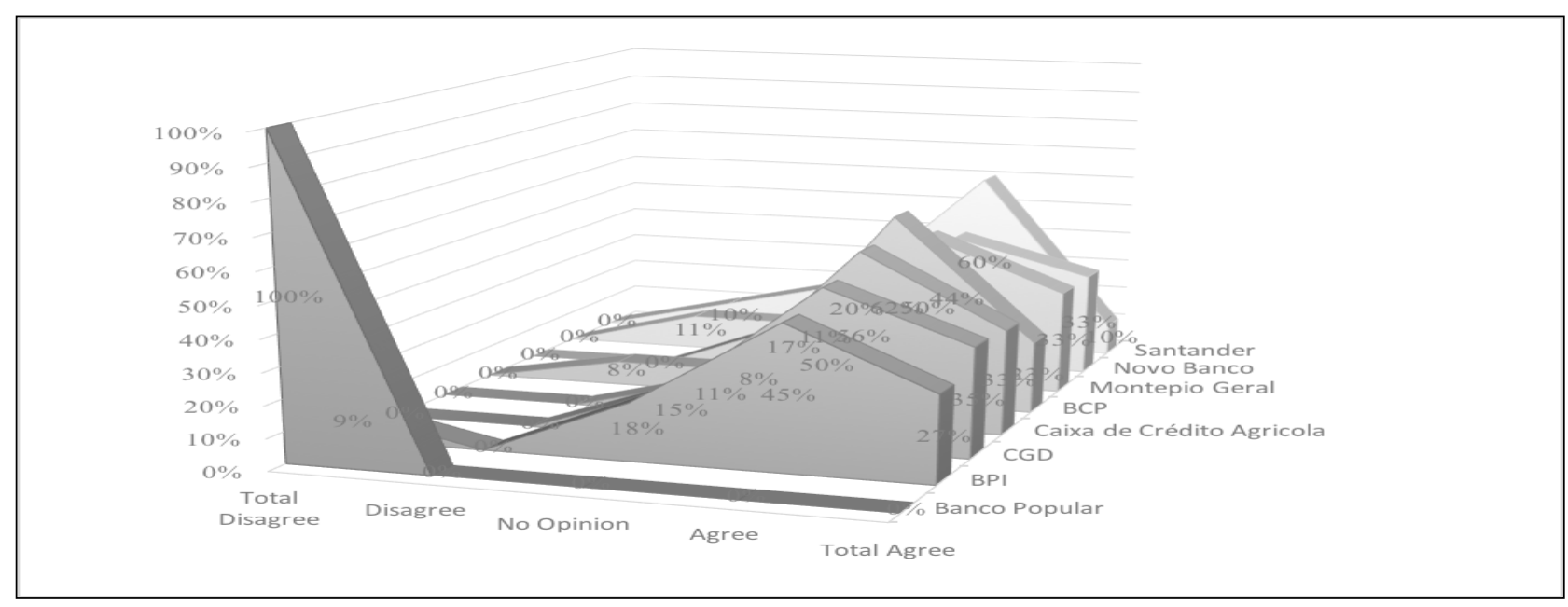




\begin{tabular}{|c|c|c|c|c|c|}
\hline 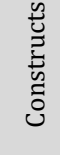 & Name & $\begin{array}{l}\text { Factor } \\
\text { scores }\end{array}$ & $\begin{array}{c}\text { Bartlett's } \\
\text { Test }\end{array}$ & $\begin{array}{c}\text { Total } \\
\text { variance } \\
\text { explained } \\
\%\end{array}$ & $\begin{array}{c}\text { Cronbach } \\
\text { Alpha }\end{array}$ \\
\hline $\begin{array}{l}\overrightarrow{\vec{D}} \\
\frac{\pi}{0} \\
\overrightarrow{0}\end{array}$ & $\begin{array}{l}\text { LOY1 } \\
\text { LOY2 }\end{array}$ & $\begin{array}{l}0,93 \\
0,93\end{array}$ & 150,065 & 92,461 & 0,912 \\
\hline 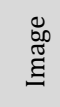 & $\begin{array}{l}\text { IM1 } \\
\text { IM2 } \\
\text { IM3 }\end{array}$ & $\begin{array}{l}0,94 \\
0,95 \\
0,82\end{array}$ & 283,696 & 86,548 & 0,921 \\
\hline 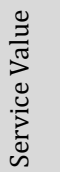 & $\begin{array}{l}\text { SV1 } \\
\text { SV2 } \\
\text { SV3 }\end{array}$ & $\begin{array}{l}0,85 \\
0,85 \\
0,81\end{array}$ & 144,839 & 75,862 & 0,839 \\
\hline
\end{tabular}

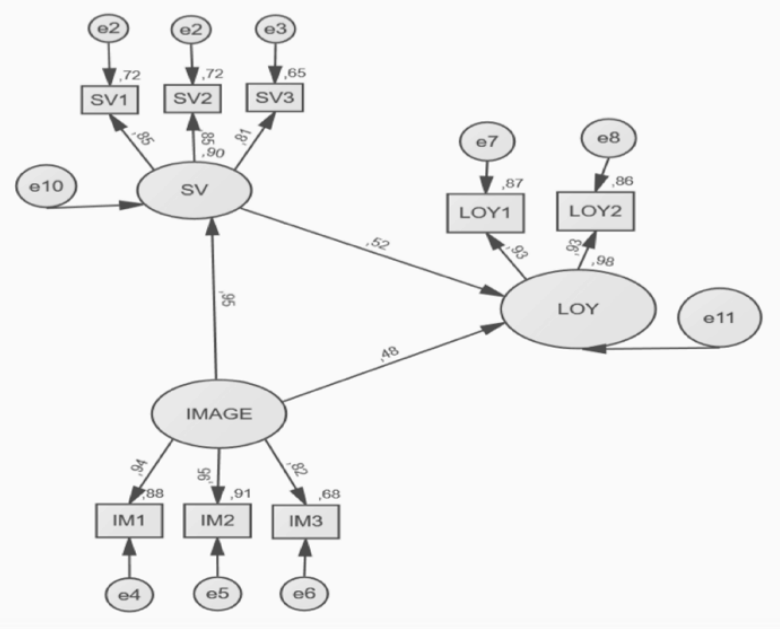

\section{CONCLUSIONS}

The present study aims to contribute to the existing literature by analyzing the variables influencing Mobile Banking Loyalty. Our findings show that Image is found to have a great impact on Service Value and Loyalty. Consequently, when mobile bank App reinforce their image, perceived service value and loyalty are directly improved. Mobile bank services' image are critical to succeed in today's increasingly competitive marketplace. On the other hand, the service perceived value also influences positively loyalty. Perceived customer value is considered as one of the most imperative factors in the study of customer intention to adopt. In this respect, perceived value is a powerful predictor in attracting new customer and retaining new ones and should thus be perceived with great importance by e-marketers. Creating customer value is considered an important consideration for companies which seek to promote competitive advantage [17]. Consequently, mobile service companies must focus their efforts on providing a positive and favorable corporate image, as well as high value. In addition, customer loyalty provides the foundation of a company' sustained competitive advantage, so retaining existing customers appears to be crucial for mobile service providers [12].

This research has several limitations, providing possible avenues for further future research. As for the main limitation of this study, first we should notice that the present research was carried out only in Portuguese market; and thus, provides a limited empirical application. Secondly, this study analyses a number of variables proposed in prior literature, which only represent a small part of all dimensions affecting mobile banking loyalty. Accordingly, market scholars and practitioners should consider variables other than those mentioned in our research. Therefore, caution must be exercised in generalizing from these findings and further research is also needed to avoid limitations. 


\section{References}

Shaikh, A.A., Karjaluoto, H. (2014). Mobile banking adoption: A literature review. Telematics and Informatics (article in press).

Yousuf, M. (2017). Examining the role of trust in shaping customer satisfaction of mobile banking (Doctoral dissertation, University Tun Hussein Onn Malaysia).

https://www.businessinsider.com/mobile-banking-market-trends.

Fragata, A., Teixeira, H. and Cruz-Lopes. L. (2018). Mobile Banking: Evidence from Portugal. Archives of Business Research, 6 (10), p.415-422.

Thakur, R. (2014). What keeps mobile banking customers loyal?. International Journal of Bank Marketing, Vol. 32 No. 7, p. 628-646. https://doi.org/10.1108/IJBM-07-2013-0062.

G. K. and Zapan, B. (2014). Bangladeshi mobile banking service quality and customer satisfaction and loyalty. Management and Marketing, 9 (3), p. 331-346.

Arcand, M., PromTep, S., Brun, I. and Rajaobelina, L. (2017), "Mobile banking service quality and customer relationships", International Journal of Bank Marketing, Vol. 35 No. 7, p. 1068-1089.

Szűts, I. \& Tóth, Z. (2006). Customer Loyalty Problems in Retail Banking. Proceeding of the MEB 2008 6th International Conference on Management Enterprise and Benchmarking. May 30-31, Budapest, Hungary, p.355361.

V.A. Zeithaml (1988). Consumer perceptions of price, quality, and value: a means-end model and synthesis of evidence, Journal of Marketing,vol. 52, p. 2-22;

K-S. Choi, W-H. Cho, S. Lee, H. Lee, and C. Kim (2004). The relationships among quality, value, satisfaction and behavioral intention in health care provider choice: a south korean study, Journal of Business Research, vol. 57, p. 913-921.

Alsheikh, L., and Bojei, J. (2012). Customer's Perceived Value to Use Mobile Banking Services. In International confernece on management, behavioural sciences and economics issues (ICMBSE2012).

Calvo-Porral, Lévy-Mangin, C. J.(2015).Switching behavior and customer satisfaction in mobile services: Analyzing virtual and traditional operators Computers in Human Behavior 49, p. 532-540.

Deng, Z., Lu, Y., Wei, K. K., and Zhang, J. (2010). Understanding customer satisfaction and loyalty: An empirical study of mobile instant messages in China? International Journal of Information Management, 30, p. $289-300$.

Zameer, H.Tara, A., Kausar, U. and Mohsin, A. (2015).Impact of service quality, corporate image and customer satisfaction towards customers' perceived value in the banking sector in Pakistan, International Journal of Bank Marketing, Vol. 33 No. 4, p. 442-456.

MitchGriffin, F., Babin, B. (2009). (2009). How quality, value, image, and satisfaction create loyalty at a Chinese Telecom. Journal of Business Research. Volume 62, Issue 10, October 2009, p. 980-986.

Hu, L., and Bentler, P. M. (1999). Cutoff criteria for fit indexes in covariance structure analysis: Conventional criteria versus new alternatives. Structural Equation Modeling, 6(1), p.1-55.

Jamil Bojei, J. and and Alsheikh, L. (2013). The Value Perspective to Adopt Mobile Banking. Pertanika J. Soc. Sci. \& Hum. 21 (S), p. $57-64$. 